\title{
ONTOGENETIC MORPHOGENESIS AND BIOGEOGRAPHIC PATTERNS: RESOLVING TAXONOMIC INCONGRUENCES WITHIN "SPECIES" OF BUCCELLA FROM SOUTH AMERICAN COASTAL WATERS
}

\author{
LYDIA CALVO-MARCILESE \\ Centro Regional Universitario Bariloche, Universidad Nacional del Comahue, INIBIOMA-CONICET, Quintral 1250, \\ San Carlos de Bariloche, 8400, Río Negro, Argentina.lydiacalvomarcilese@yahoo.com.ar
}

\author{
MARTIN R. LANGER
}

Steinmann Institut für Geologie, Mineralogie und Paläontologie, Rheinische Friedrich-Wilhelms Universität, Nussallee 8, 53115, Bonn, Germany. martin.langer@uni-bonn.de

\begin{abstract}
The analysis of ubiquitous material of individual growth stages of the foraminifer Buccella from the Bahía Blanca estuary reveals a wide range of morphogenetic expressions. The observations of morphological changes expressed during ontogeny display a continuous record of transitional stages that are reflected in juvenile, adolescent, and adult test shapes. The morphological features of individual growth stages were found to match specifications that were previously used to delineate individual species of Buccella from around South America. This indicates that juvenile, adolescent, and adult morphotypes of Buccella do not represent end members of individual species, subspecies, forms, or varieties. In fact, they constitute a continuous sequence of ontogenetic stages that ultimately result in the morphotype that was originally described and depicted by d'Orbigny, in the first half of the nineteenth century, under the name Rotalina peruviana (currently known as Buccella peruviana). The morphological expressions of juvenile, adolescent, and adult forms have potential applications for paleoecological studies in South American waters.
\end{abstract}

Key words: Foraminifera, Protist, morphogenesis, ontogeny, taxonomy, biogeography.

RESUMO - A análise das diferentes fases de crescimento do foraminífero Buccella, com base em rico material recuperado do Estuário de Bahia Blanca, revelou uma vasta gama de expressões morfogenéticas. As observações de alterações morfológicas durante a ontogenia estão expressas num registo contínuo de estágios transicionais que estão refletidos nas diferentes fases de crescimento, i.e., nos juvenis, adolescentes e adultos. As características morfológicas das fases individuais de crescimento coincidem com as especificações utilizadas anteriormente no delineamento individual das espécies de Buccella originárias da América do Sul. Isto significa que os diferentes morfotipos correspondentes às fases juvenil, adolescente e adulto no gênero Buccella não representam membros finais de espécie, subespécie, forma ou variedade. Na verdade, eles constituem uma sequência contínua de fases ontogénicas que, em última análise, resultam no morfotipo originalmente descrito e retratado por d'Orbigny, na primeira metade do século dezenove, sob o nome Rotalina peruviana (atualmente denominada Buccella peruviana). As expressões morfológicas de formas juvenis, adolescentes e adultas têm aplicações potenciais para estudos paleoecológicos em águas sul-americanas.

Palavras-chave: Foraminifera, Protista, morfogênese, ontogênese, taxonomia, biogeografia.

\section{INTRODUCTION}

Foraminifera are prominent components in both current and ancient shallow ocean settings along the southern coastlines of the South American continent (Boltovskoy, 1954a,b, 1970). Among the diverse assemblages of benthic taxa recorded, the species of the genus Buccella Andersen,1952 were reported to be ubiquitous, and the most common shallow benthic foraminifers encountered along the Pacific coast between Peru and Buenos Aires, in the Atlantic off Argentina (Cushman \& Parker 1931; Heron-Allen \& Earland, 1932; Boltovskoy 1954a,b, 1957, 1959, 1963, 1976; Boltovskoy \& Theyer, 1965; Theyer,
1966). Cushman \& Parker (1931), who studied material from Patagonian harbours and the Malvinas (= Falkland) Islands, were the first to note that Buccella is very widely distributed along the South American coast. Large-scale biogeographic studies later confirmed that foraminifera of the genus Buccella are the most frequently encountered taxa, such that the southern part of South America has since been called a "Buccella kingdom" by some foraminiferologists (Theyer, 1966; Boltovskoy, 1970, 1976).

To date, a total of more than 40 living and fossil species of Buccella are described. As in many other planoconvex trochospiral foraminifera (e.g. genus Ammonia), some species of 
Buccella exhibit pronounced morphological plasticity (Theyer, 1966). As a consequence and in the absence of a consistently applied species concept, Buccella species delineations remained controversial and a matter of debate. Along the coast of Argentina and Brazil, for example, the species Buccella peruviana (d'Orbigny) has been described under at least seven different names and variously been named Eponides peruvianus (d'Orbigny), E. karsteni (Reuss), E. frigidus (Cushman), E. peruvianus campsi (Cushman), Buccella frigida (Cushman), $B$. peruviana f. campsi (Boltovskoy), B. peruviana (d'Orbigny) or B. cf. inusitata (Andersen). This debate largely resulted from opposing views of "lumpers" and "splitters" but has important implications for such things as estimates of biodiversity, clearly illustrating the need for intensified taxonomic efforts. Nowadays, the issues of how many species of Buccella live within the South Atlantic shallow waters off Argentina, Uruguay and Brazil has not yet been resolved.

Recent specimens of Buccella from South America were recognized by d'Orbigny as early as 1839 . He described and illustrated three species of Buccella (originally placed in the genus Rotalina): B. peruviana from Peru, B. alvarezii from Patagonia and the Malvinas (= Falkland) Islands, and B. patagonica from Patagonia. In 1884, Brady illustrates individuals of another species, Buccella karsteni (Reuss) from the Magellan Strait (Chile), originally placed in the genus Pulvinulina. However, this species was firstly described from Cretaceous deposits (Reuss, 1855). Heron-Allen \& Earland (1932) reported on the foraminifera from the Malvinas (= Falkland) Islands and adjacent seas in the South Atlantic. They noted the presence of four species of Buccella (registered by them in the genus Pulvinulina), B. patagonica, B. alvarezii, $B$. peruviana and $B$. karsteni, confirming the presence of these species in South Atlantic waters. Cushman (1921) suggested the separation of Recent forms from their fossil counterparts, and preferred the species name Buccella frigida (Cushman) instead of B. karsteni. However, B. frigida was originally described from Arctic waters in the northern hemisphere (Hudson Bay, $60^{\circ} \mathrm{N}$ ) (Cushman, 1921). Because Heron-Allen \& Earland (1932) considered B. karsteni to be "subject to great variation", the species name $B$. frigida is still frequently used in modern literature. Interestingly, Heron-Allen \& Earland (1932) acknowledged that the analysis of sutures, shell convexity and number of chambers indicated that intermediate forms exist between $B$. karsteni and B. peruviana. The result was the later authors accepted the separation of Recent and fossil species (as suggested by Cushman) but were inconclusive as to where to place the specimens of the putative Cretaceous species $B$. karsteni of Reuss. Some authors followed Cushman (1921) and included their individuals in B. frigida, while others followed Heron-Allen \& Earland (1932) and considered the specimens of $B$. karsteni to be members of B. peruviana. To this date, this issue has not been resolved.

From the original three species described by d'Orbigny, two were simply ignored by later workers and slowly disappeared in the literature: Buccella alvarezii and B. patagonica. The reason for this is not clear, but Heron-Allen \& Earland (1932) mention that the type specimens of $B$. alvarezii has been lost in Paris and that the type specimens of $B$. patagonica "has been mishandled by some curator without much knowledge of the subject". It thus appears that from the original four species of Buccella described from around South America, only two were accepted by foraminiferologist as valid constituents of the Recent fauna: B. peruviana (d'Orbigny, 1839) and B. frigida (Cushman, 1921).

More than three decades after the publications of Heron-Allen \& Earland (1932), Theyer (1966) conducted a large-scale biogeographic study, comparing and analyzing Buccella specimens from all around South America (Pacific and Atlantic). He concluded that two species of Buccella live in the studied area: $B$. peruviana in the Pacific from Peru down to $42^{\circ} \mathrm{S}$ off Chile, and $B$. frigida from approximately $42^{\circ} \mathrm{S}$ in the Pacific all around Cape Horn and north into the Atlantic along the coast of Argentina, Uruguay and Brazil. Thus, he followed the concept of Cushman (1921) not Heron-Allen \& Earland (1932) and ignored the statement of Parker \& Jones (1865) that $B$. frigida is "evidently an Arctic species of definite distribution..." that differs from the Pacific form B. peruviana (e.g. Cushman \& Kellett, 1929; Cushman \& Parker, 1931).

To complicate things even further, Boltovskoy $(1954 a, b)$ and Theyer (1966) noted that Buccella peruviana exhibits a large range of morphological variations, and that the three end members of these morphological variants deserve different names with the status of subspecies, variants or forms: $B$. peruviana f. typica, B. peruviana f. frigida and B. peruviana f. campsi. As a consequence, they have been differently named by various authors in the Chilean, Argentinian and Brazilian coastal waters (Boltovskoy, 1954a,b, 1957; Closs \& Barberena, 1960; Theyer, 1966; Boltovskoy et al., 1980; Laprida, 1998; Caramés \& Malumián, 2000; Cusminsky et al., 2006, 2009; Ferrero, 2006; Eichler et al., 2007). In 1970, however, Boltovskoy concluded that only a single species, $B$. peruviana, is present throughout the entire area, and that the previously described subspecies, variants or forms represent ecophenotypic end members of the species. Modern works on Recent foraminifera from this region show that the late conviction of Boltovskoy's concept of a single species of Buccella has not been accepted by all the foraminiferologists. The contemporaneous use of the two most common species, B. peruviana and B. frigida, is still in use. A potential source for taxonomic disagreement among foraminiferologists is the chronic negligence of morphological changes that are associated with the skeletal development (morphogenesis) during test ontogeny (Langer \& Schmidt-Sinns, 2006). This paper illustrates ontogenetic growth stages of Buccella specimens from the Bahía Blanca estuary to document patterns of morphogenesis and test differentiation during growth (juvenile, adolescent, and adult). The range and plasticity of morphological expressions exhibited during ontogeny is then used to assess the validity of previously described "species" of Buccella from the coast of Argentina. In this paper the authors take advantage of the ubiquitous material of Buccella from the Bahía Blanca estuary, to provide detailed description of individual growth stages. 


\section{MATERIAL AND METHODS}

The foraminiferal material analyzed for this study was collected from various sites within and off the Bahía Blanca estuary, South Atlantic, Argentina (Figure 1). This estuary occupies a large coastal area in the south of the Buenos Aires province $\left(38^{\circ} 44^{\prime}-39^{\circ} 26^{\prime} \mathrm{S}, 62^{\circ} 35^{\prime}-62^{\circ} 05^{\prime} \mathrm{W}\right)$. It is characterized by a dense network of channels of different sizes, usually of meandering type. Numerous islands and flat areas separated by extensive tidal flats complete the coastal physiography of the estuary. The main channel of the estuary (Canal Principal) is more than $60 \mathrm{~km}$ in length and is the site of one of the most important port systems along the coast of Argentina.

Sediment samples containing Buccella specimens were collected from sample sites (Figure 1) along four surface cross transects: (Arroyo Maldonado [M], Club Almirante Brown [B], Tres Brazas [TB] and Villa del Mar [V]) and from three outcrops (Arroyo Napostá [N1], Canal Tres Brazas [C3B] and Canal del Medio [CdM]; and a core PS2B2). For additional details the reader is referred to Cusminsky et al. (2006), Calvo-Marcilese \& Pratolongo (2009), Calvo-Marcilese \& Langer (2010) and Calvo-Marcilese et al. (2011).

Microfaunal collection and analyses were conducted following standard protocols of Boltovskoy (1965). Scanning electron microscope (SEM) pictures were taken at the Centro Atómico Bariloche, Argentina, using a Philips SEM 515 and at the Steinmann Institute-University of Bonn, Germany, using a Tescan-Digital Microscopy Imaging-Vega-Column Type Ts 53201 No. Vg0190171b.
To document a continuous series of growth stages in individuals of Buccella, 160 specimens were measured, documented by SEM and morphological features were recorded.

\section{RESULTS}

To document the full range of test features expressed in specimens of Buccella during ontogeny, a continuous record of growth stages has been recorded via scanning electron microscopy. In the following has been described the three principal stages of development in Buccella: (i) juvenile $(\leq 300$ $\mu \mathrm{m})$, (ii) adolescent $(301-380 \mu \mathrm{m})$ and (iii) adult $(>380 \mu \mathrm{m})$. For the descriptions presented below, the authors have recorded all test characteristics that are currently used as features to distinguish among individual species. They include the test diameter of the dorsal surface, the number of chambers in the last coil, the maximum number of coils present in the adult stage, the general test shape in the adult stage, the peripheral outline of the test, the form and shape of the periphery, the presence/ absence of a keel, the form of the sutures on the ventral and the dorsal side of the test, and finally the ornamentation on the ventral side (Table 2).

\section{Comparative morphology: growth stages of Buccella}

Juvenile stage. Juvenile specimens $(<300 \mu \mathrm{m})$ of Buccella from Bahía Blanca exhibit the typical trochospiral chamber arrangement of the calcareous test ( 60 specimens). The chambers are slightly inflated (at least on the umbilical side, Figures 2A3, B2, D2). Juvenile individuals commonly have five chambers in

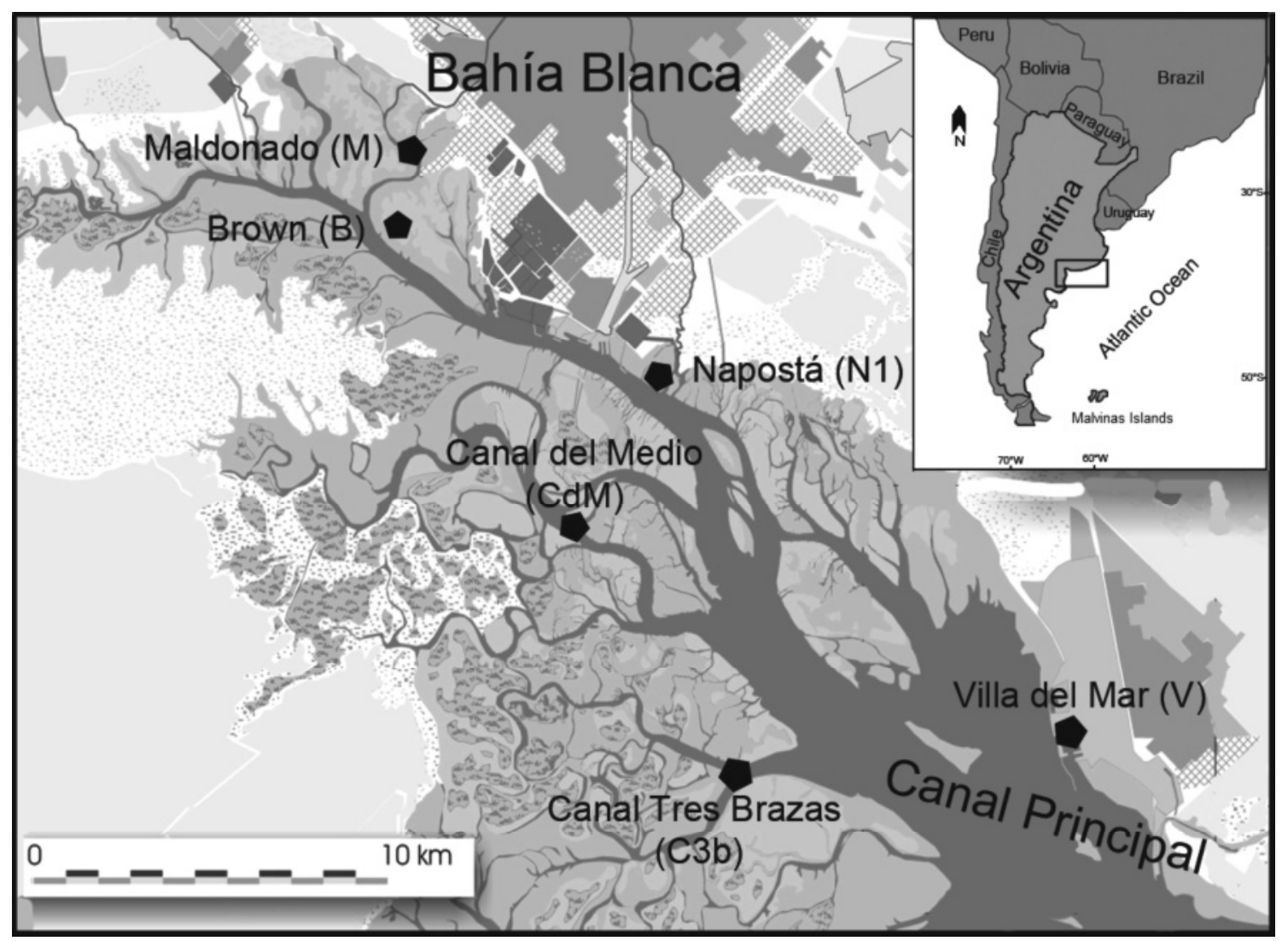

Figure 1. Location map of the Bahía Blanca estuary and the analyzed sections. 
the last coil and display between 1.2 and 1.5 coils on the dorsal side. In side view, the tests display a slightly dorsoconvex to faintly biconvex outline with a subangular periphery (Figures 2B1, C1). At this stage, juvenile individuals lack a well developed peripheral keel. Dorsal sutures are slightly to distinctly arcuate and generally flush with the surface except for the ultimate half whorl, where they are depressed. Ventral sutures are radial or slightly arcuate, bent backwards and flush at the periphery, but sinking rapidly towards the umbilicus and thus producing an intraseptal space that is densely covered by minute pustules. In most specimens the umbilical area is also covered by pustulate ornamentation. The peripheral outline of the test is subcircular but slightly more lobulate in the ultimate half whorl. The juvenile forms correspond well with what was previously considered to be Buccella frigida of Cushman (1921) or B. peruviana f. frigida of Boltovskoy (1954a,b).

Adolescent stage. Adolescent specimens (301-380 $\mu \mathrm{m})$ of Buccella usually have six to seven chambers in the final whorl (60 specimens). The chambers are trochospirally arranged, crescentic to kidney-shaped on the dorsal side and subtriangular and slightly inflated on the ventral side. Adolescent individuals display up to 2.4 volutions on the dorsal side. Tests are mostly biconvex to lenticular in side view with a generally more pronounced ventroconvex side. At this stage, the degree of convexity of the test is variable (Figures 2E1, H). The peripheral margin is angular and characterized by a faintly developed and slightly thickened keel. Dorsal sutures are slightly arcuate and generally flush with the surface except for the ultimately half whorl, where they are depressed (Figures $2 \mathrm{~F}, \mathrm{~J})$. Ventral sutures are radial or slightly arcuate, flush at the periphery, but deeply incised towards the umbilical area thus producing a depressed intraseptal space that is densely covered by pustules (Figures 2G, J, K). The umbilical part of the interlocular intraseptal space and the umbilical area are sometimes covered by fused and thus somewhat larger pustules that mask the umbilical area. The peripheral outline of the test is subcircular to faintly lobulate. Lobulation is most pronounced in the ultimate three to five chambers but distinctly smoothed by the keeled peripheral margin. The adolescent forms correspond well with what was previously considered to be Buccella karsteni of Heron-Allen \& Earland (1932), B. alvarezii of d'Orbigny (1839), juvenile to adolescent forms of $B$. peruviana f. typica of Boltovskoy (1954a,b), adolescent forms of B. peruviana f. campsi of Boltovskoy (1954a,b), and sometimes, in particular in the more planoconvex forms, B. patagonica of d'Orbigny (1839) and Heron-Allen \& Earland (1932).

Adult stage. Fully adult specimens of Buccella from Bahía Blanca $(>380 \mu \mathrm{m})$ exhibit a biconvex and lenticular test that is often characterized by a distinct peripheral keel (Figures 2L-O). Up to nine chambers are visible in final whorl of adult forms and specimens may reach $444 \mu \mathrm{m}$ in diameter (40 specimens). The chambers are crescentic to kidney-shaped on the spiral side and triangular and slightly inflated on the umbilical side. The triangular chambers on the umbilical side, a feature that is typical of adult B. peruviana as described by d'Orbigny (1839), resemble thinly cut pie slices.

Adult individuals display up to 3.0 volutions on the dorsal side. Dorsal sutures are slightly arcuate and generally flush with the surface (Figure 2N). Ventral sutures are radial and deeply depressed towards the umbilical area thus producing an incised intraseptal space (Figures 2M,O). The intraseptal space is masked by small pustules that densely cover the sutures and the umbilical region. Within the umbilical part of the interlocular intraseptal space and in the umbilical area, the pustules sometimes fuse to produce larger pustules. The peripheral outline of the test is subcircular to faintly lobulate. Lobulation is most pronounced in the ultimate three to five chambers but distinctly smoothed by the keeled peripheral margin. The adult forms correspond well with what was previously considered to be Buccella peruviana of d'Orbigny (1839), B. peruviana f. typica of Boltovskoy (1954a,b), and larger forms of B. peruviana f. campsi of Boltovskoy (1954a,b).

The analysis of ubiquitous material of individual growth stages of Buccella from the Bahía Blanca estuary displays a wide range of morphogenetic expressions. The observations of morphogenetic changes expressed during ontogeny, show a multitude of transitional stages. This suggests that all specimens of Buccella recovered from the Bahía Blanca estuary are representative of a single species.

\section{Biogeography}

Local distribution. This species of Buccella is widely distributed in the Bahía Blanca estuary (Cusminsky et al., 2006, 2009; Calvo-Marcilese et al., 2011). It has also been recorded in Holocene material from Bahía Blanca (see sections N1, PS2B2, CdM, C3B in the Figure 1 of this paper, and Gómez et al., 2005; Cusminsky et al., 2009; Calvo-Marcilese et al., 2011) and from late Holocene deposits along north- and south-eastern Buenos Aires province (Boltovskoy, 1970, 1976; Laprida, 1998; Laprida et al., 2007; Ferrero, 2006; Alperin et al., 2011). In present-day Bahía Blanca estuary material, Buccella is widely distributed in subtidal and inner shelf environments but has rarely been recovered from intertidal habitats (Cusminsky et al., 2006; Calvo-Marcilese $\&$ Pratolongo, 2009). The species has also been recorded from inner shelf settings in the Buenos Aires province and from the Golfo Nuevo, Chubut (Bernasconi, 2006).

Distribution around South America. Ubiquitous material of Buccella has frequently been reported from all around South America. This includes the classic east Pacific locations from Peru (Callao, $12^{\circ} \mathrm{S}$ ) to the coast of Chile into the Magellan Strait and around Cape Horn into the Atlantic along the coast of Argentina, Uruguay (Perforación Chuy) and southern Brazil (Patos Lagoon, summarized in Theyer, 1966; Sprechmann, 1978; Boltovskoy et al., 1980). Abundant material of Buccella has also been reported from the Malvinas (= Falkland) Islands

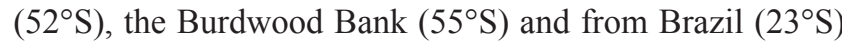
(Cushman \& Parker, 1931; Heron-Allen \& Earland,1932; Eichler et al., 2007). The abundance and distributional pattern of Buccella along the coast of Argentina, Uruguay and Brazil, led Boltovskoy (1976) to consider the area as the "Argentine" zoogeographic province, an independent biogeographical province that extends from the Cape Horn to the South of Brazil (Patos Lagoon). 


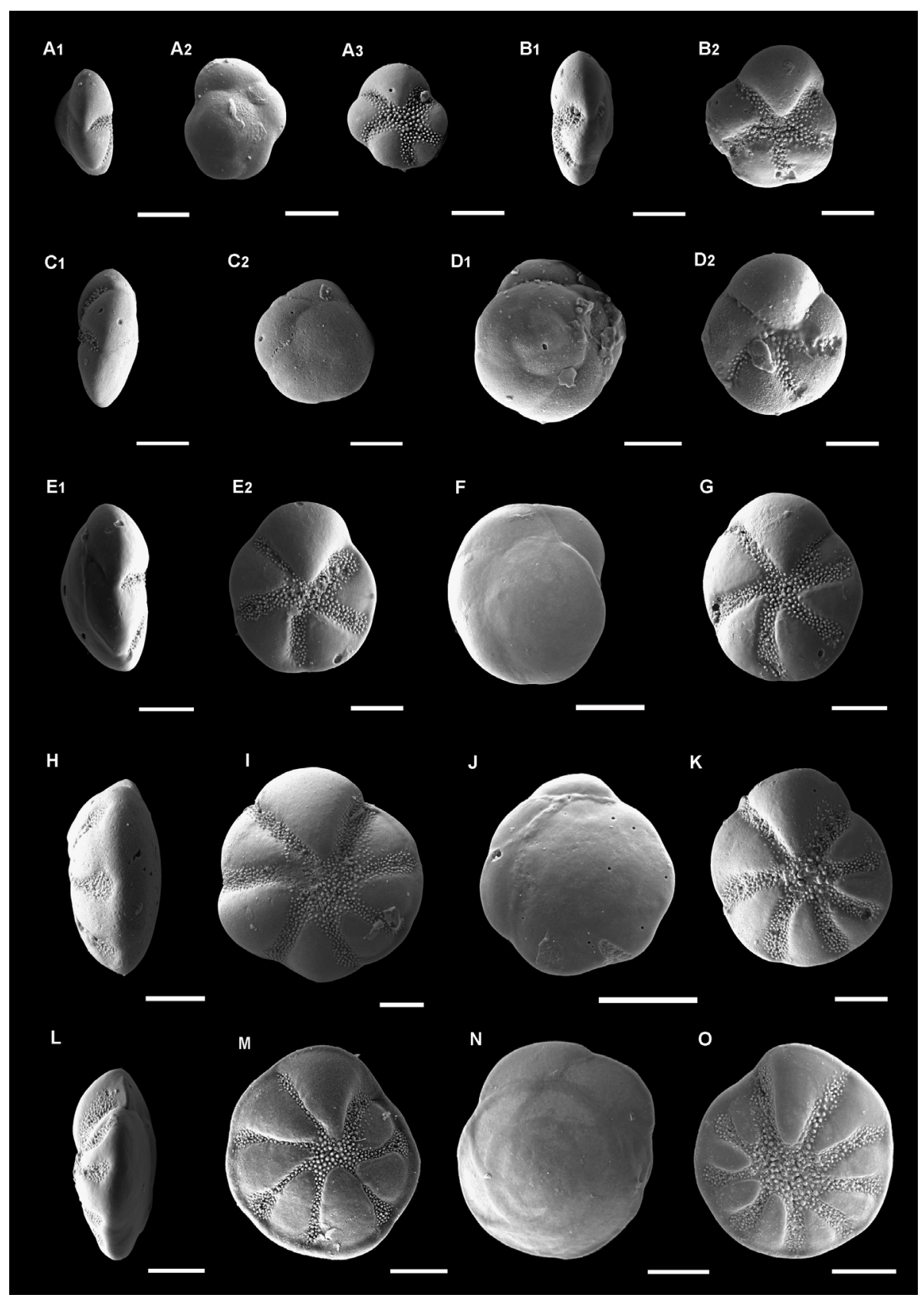

Figure 2. Documentation of continuous growth stages of Buccella peruviana arranged from juvenile-adolescent-adult. A1, profile view of a juvenile individual showing the convexity of the test. Note the angular to subrounded test periphery and the absence of a keel; A2, spiral view displaying faintly backwards curved sutures and a weakly lobulated periphery. Note the lack of a keel; $\mathbf{A} 3$, umbilical view of juvenile individual with five slightly inflated and subtriangular chambers, radial to slightly curved sutures and an umbilical area that is densely covered by pustules. Note the angular peripheral margin; B1, profile view of juvenile individual, exhibiting a weakly biconvex test form; B2, umbilical view of five-chambered individual with a subcircular to weakly lobulated peripheral margin, radial and incised sutures and pustulated umbilical area. Note the presence of minute relict openings into incised sutural fissures near the peripheral test margin; $\mathbf{C 1}$, profile view of juvenile individual, with lenticular to slightly dorsoconvex test and angular peripheral margin; C2, spiral view of a juvenile individual with subcircular and weakly lobulated peripheral outline and smooth test surface; D1, spiral view of a five-chambered individual with backwards curved sutures that are flush to weakly incised. Note the subrounded to weakly lobulated peripheral outline; D2, umbilical view of a specimen with a subcircular peripheral outline, slightly inflated chambers, backwards curved incised sutures, pustulated umbilical area, and asymmetrically subtriangular chambers; E1, profile view of an adolescent individual showing a lenticular but slightly more dorsoconvex foraminiferal test with angular periphery; E2, umbilical view. Note the subtriangular form of the chambers, radial and distinctly pustulated sutures and the initiation of keeled periphery; F1, dorsal side of an adolescent specimen with subrounded periphera outline, sub-quadrangular chambers and delicately depressed sutures; $\mathbf{G}$, umbilical view of a six-chambered individual with pie-like triangular chambers and densely pustulated sutures; $\mathbf{H}$, profile view of adolescent individual with lenticular but more ventroconvex test form; I, umbilical view of a seven-chambered individual with radial, depressed and pustulated sutures and subtriangular chambers. Note the slightly thickened keel along the peripheral margin; $\mathbf{J}$, side view of transitional adolescent to adult individual with seven chambers and smooth test surface; $\mathbf{K}$, umbilical view of a seven chambered specimens with triangular chambers and incised and strongly pustulated sutural and umbilical areas. Note the keel surrounding the periphery of the faintly lobulated test; $L$, side view of an adult specimen displaying a lenticular biconvex test with angular periphery; $\mathbf{M}$, umbilical view of a seven-chambered test with pronounced peripheral keel, triangular chambers and distinct pustulation along sutural lines and umbilical area; $\mathbf{N}$, dorsal (spiral) view of a seven-chambered large adult individual. Note the visibility of the spiral suture lines, the angular periphery and the keel around the peripheral margin; $\mathbf{0}$, umbilical view of adult individual with nine triangular chambers in the last coil. Note that the chambers on the umbilical side of the test have transformed from subtriangular and slightly inflated in juvenile to sharply triangular in adult tests and that the peripheral angle has changed from subrounded in juvenile to angular and keeled in adult specimens. Scale bars $=100 \mu \mathrm{m}$. 


\section{DISCUSSION}

Recent years have seen significant progress in the knowledge of biodiversity (Purvis \& Hector, 2000; Sala \& Knowlton, 2006; Tittensor et al., 2010). Among the most commonly used facets considered of biodiversity, the measure of species richness has made foraminiferologists increasingly aware of global gradients and associated environmental factors. Almost 200 years of research on foraminifera around the South American continent have provided a detailed account of the diversity and distribution of foraminiferal species (Boltovskoy, 1976; Boltovskoy et al., 1980). Among them, species of Buccella were recorded as the most prominent and frequently encountered taxa in shallow-water habitats $(<200 \mathrm{~m})$. Up to five species of Buccella were recorded from this region (Table 1).
To date, however, researchers have not reached a consensus of exactly how many species of Buccella live within this region. Particularly problematic was the fact that many "species" often exhibit transitional forms between other species and a range of morphological variations. Symptomatic of the confusion are several statements by Heron-Allen \& Earland (1932) who, for example, mentioned that “....it seems probable that the species Pulvinulina alvarezii represents only a transition from Pulvinulina karsteni and Pulvinulina peruviana" (as already noted above, currently these species belong to the genus Buccella). The same authors also noted that "the species 'Pulvinulina' alvarezii is of great variation" and that the features "indicate a form intermediate between Pulvinulina karsteni and Pulvinulina peruviana". The species Buccella peruviana is considered by Heron-Allen \& Earland (1932) to

Table 1. Characteristics of Buccella species registered in the literature.

\begin{tabular}{|c|c|c|c|c|c|c|c|}
\hline $\begin{array}{l}\text { Morphological } \\
\text { features of each } \\
\text { species }\end{array}$ & $\begin{array}{c}\text { B. peruviana } \\
\text { d'Orbigny, } \\
1839\end{array}$ & $\begin{array}{c}\text { B. alvarezii } \\
\text { d'Orbigny, } \\
1839\end{array}$ & $\begin{array}{c}\text { B. patagonica } \\
\text { d'Orbigny, } \\
1839\end{array}$ & $\begin{array}{c}\text { B. frigida } \\
\text { Cushman, } 1921\end{array}$ & $\begin{array}{l}\text { B. karsteni } \\
\text { Brady, } 1884\end{array}$ & $\begin{array}{c}\text { B. peruviana } \\
\text { forma campsi } \\
\text { Boltovskoy et } \\
\quad \text { al., } 1980\end{array}$ & $\begin{array}{c}\text { Buccella } \\
\text { Bahía Blanca } \\
\text { Calvo-Marcilese, } \\
2011\end{array}$ \\
\hline Diameter (mm) & $0.25-0.54$ & $0.25-0.54$ & $0.25-0.54$ & $0.17-0.47$ & $0.25-0.57$ & $0.25-0.63$ & $0.17-0.44$ \\
\hline $\begin{array}{c}\text { Number of } \\
\text { chambers in the } \\
\text { last coil }\end{array}$ & $5-11$ & $5-7$ & $5-7$ & $5-9.5$ & $5-9$ & $5-9$ & $5-9$ \\
\hline $\begin{array}{c}\text { Number of coils } \\
\text { in the adult } \\
\text { stage }\end{array}$ & 3.2 & 2.5 & 2.2 & 2.5 & 3.3 & 3.0 & 2.9 \\
\hline $\begin{array}{l}\text { Test shape in the } \\
\text { adult stage }\end{array}$ & $\begin{array}{c}\text { lenticular to } \\
\text { assymetrically } \\
\text { biconvex }\end{array}$ & $\begin{array}{l}\text { dorsoconvex to } \\
\text { biconvex }\end{array}$ & $\begin{array}{l}\text { lenticular to } \\
\text { assymetrically } \\
\text { biconvex }\end{array}$ & $\begin{array}{l}\text { dorsoconvex to } \\
\text { assymetrically } \\
\text { biconvex }\end{array}$ & $\begin{array}{c}\text { lenticular to } \\
\text { assymetrically } \\
\text { biconvex }\end{array}$ & $\begin{array}{c}\text { lenticular to } \\
\text { assymetrically } \\
\text { biconvex }\end{array}$ & $\begin{array}{c}\text { lenticular to } \\
\text { assymetrically } \\
\text { biconvex }\end{array}$ \\
\hline $\begin{array}{l}\text { Peripheral } \\
\text { outline }\end{array}$ & $\begin{array}{l}\text { subcircular, } \\
\text { slightly } \\
\text { lobulate }\end{array}$ & $\begin{array}{l}\text { subcircular, } \\
\text { faintly } \\
\text { lobulate }\end{array}$ & $\begin{array}{l}\text { subcircular, } \\
\text { slightly } \\
\text { lobulate }\end{array}$ & $\begin{array}{l}\text { subcircular, } \\
\text { slightly } \\
\text { lobulate }\end{array}$ & $\begin{array}{l}\text { subcircular, } \\
\text { slightly } \\
\text { lobulate }\end{array}$ & $\begin{array}{l}\text { subcircular, } \\
\text { slightly } \\
\text { lobulate }\end{array}$ & $\begin{array}{c}\text { subcircular, } \\
\text { slightly } \\
\text { lobulate }\end{array}$ \\
\hline Periphery & angular & angular & angular & subangular & angular & angular & angular \\
\hline Keel & $\begin{array}{l}\text { faintly to } \\
\text { distinctly } \\
\text { keeled }\end{array}$ & $\begin{array}{l}\text { faintly to } \\
\text { distinctly } \\
\text { keeled }\end{array}$ & $\begin{array}{l}\text { faintly } \\
\text { keeled }\end{array}$ & $\begin{array}{l}\text { faintly } \\
\text { keeled }\end{array}$ & $\begin{array}{l}\text { faintly to } \\
\text { distinctly } \\
\text { keeled }\end{array}$ & $\begin{array}{l}\text { faintly } \\
\text { keeled }\end{array}$ & - \\
\hline $\begin{array}{c}\text { Sutures } \\
\text { (ventral side) }\end{array}$ & radial & radial & $\begin{array}{c}\text { radial to } \\
\text { slightly arcuate }\end{array}$ & $\begin{array}{c}\text { radial to } \\
\text { slightly arcuate }\end{array}$ & radial & radial & $\begin{array}{c}\text { radial to } \\
\text { slightly arcuate }\end{array}$ \\
\hline $\begin{array}{c}\text { Sutures } \\
\text { (dorsal side) }\end{array}$ & $\begin{array}{l}\text { slightly to } \\
\text { distinctly } \\
\text { arcuate }\end{array}$ & $\begin{array}{l}\text { slightly to } \\
\text { distinctly } \\
\text { arcuate }\end{array}$ & $\begin{array}{l}\text { slightly to } \\
\text { distinctly } \\
\text { arcuate }\end{array}$ & $\begin{array}{l}\text { slightly to } \\
\text { distinctly } \\
\text { arcuate }\end{array}$ & $\begin{array}{l}\text { slightly to } \\
\text { distinctly } \\
\text { arcuate }\end{array}$ & $\begin{array}{l}\text { slightly } \\
\text { arcuate }\end{array}$ & $\begin{array}{l}\text { slightly to } \\
\text { distinctly } \\
\text { arcuate }\end{array}$ \\
\hline $\begin{array}{l}\text { Ornamentation } \\
\text { (ventral side) }\end{array}$ & $\begin{array}{c}\text { densely } \\
\text { pustulated } \\
\text { umbilicus } \\
\text { and along } \\
\text { interlocular } \\
\text { spaces }\end{array}$ & $\begin{array}{c}\text { densely } \\
\text { pustulated } \\
\text { umbilicus } \\
\text { and along } \\
\text { interlocular } \\
\text { spaces }\end{array}$ & $\begin{array}{l}\text { pustules } \\
\text { lacking }\end{array}$ & $\begin{array}{c}\text { densely } \\
\text { pustulated } \\
\text { umbilicus } \\
\text { and along } \\
\text { interlocular } \\
\text { spaces }\end{array}$ & $\begin{array}{c}\text { densely } \\
\text { pustulated } \\
\text { umbilicus } \\
\text { and along } \\
\text { interlocular } \\
\text { spaces }\end{array}$ & $\begin{array}{c}\text { densely } \\
\text { pustulated } \\
\text { umbilicus } \\
\text { and along } \\
\text { interlocular } \\
\text { spaces }\end{array}$ & $\begin{array}{c}\text { densely } \\
\text { pustulated } \\
\text { umbilicus } \\
\text { and along } \\
\text { interlocular } \\
\text { spaces }\end{array}$ \\
\hline
\end{tabular}


be "very closely related" to Buccella karsteni and the authors suggested the possibility that both forms may simply be Atlantic and Pacific variants.

The type species of Buccella from South America were originally described by d'Orbigny (1839) who depicted apparently adult forms that differed in the number and form of chambers and the convexity of the test. As such he considered them to represent end members of three species: Buccella alvarezii (Cushman), Buccella peruviana (d'Orbigny), and Buccella patagonica (d'Orbigny). However, whether the monotypic end member of these 'species' represent true biological entities or simply morphogenetic stages that appear during ontogeny, had not been considered by d'Orbigny (1839), Cushman (1921), Heron-Allen \& Earland (1932) and subsequent authors. Recent observations of significant phenetic plasticity expressed during ontogeny have shed new light on validity of monotypic species concepts in foraminifera (Langer \& Schmidt-Sinns, 2006).

This study of the individual growth stages of Buccella from the Bahía Blanca estuary also reveals substantial morphogenetic transformations expressed during ontogeny (Figure 2). Detailed examination of ubiquitous material thus allowed these authors to identify a continuous set of subsequent growth stages that show transitional and intergrading morphotypes from juveniles to large adults. Based on the size of Buccella tests, the growth stages were subdivided into three categories: juvenile, adolescent, and adult.

As noted above, the series of stages expressed during growth in Buccella from Bahía Blanca displays a continuous record of specimens with five (juvenile) to a maximum of nine chambers (adult) and a size range from $188 \mu \mathrm{m}$ to a maximum of $444 \mu \mathrm{m}$. The continuum of morphogenetic stages supports the conclusion that only a single species is present within the estuary. This diagnosis is also corroborated by the finding that juvenile tests display up to 1.5 , adolescent up to 2.4 and adult test up to 3 volutions in the final coil on their dorsal side. The accretion of chambers displayed during ontogeny in Buccella thus matches with the figures and descriptions of Buccella peruviana of d'Orbigny (1839), of juvenile to adult forms of B. peruviana f. typica of Boltovskoy et al. (1980), B. peruviana f. campsi of Boltovskoy et al. (1980), B. karsteni (Reuss) of Heron-Allen \& Earland (1932), and B. alvarezii (d'Orbigny) of Heron-Allen \& Earland (1932).

The test convexity observed during growth reveals that juvenile forms are slightly dorsoconvex to faintly biconvex and adolescent and adult forms asymmetrically biconvex and

Table 2. Morphological features of Buccella species recovered in the study area.

\begin{tabular}{|c|c|c|c|c|}
\hline Morphological & Juveniles & Adolescents & Adults & All specimens from \\
\hline features of each size class & $\leq 300 \mu \mathrm{m}$ & $301-380 \mu \mathrm{m}$ & $>380 \mu \mathrm{m}$ & Bahía Blanca \\
\hline Diameter (mm) & $\leq 0.3$ & $0.301-0.38$ & $>0.38$ & $0.17-0.44$ \\
\hline $\begin{array}{l}\text { Number of chambers in } \\
\text { the last coil }\end{array}$ & 5 & $6-7$ & 9 & $5-9$ \\
\hline Number of coils & $1.2-1.5$ & 2.4 & 3 & 2.9 (adults) \\
\hline Test shape & lenticular slightly inflated & biconvex and lenticular & biconvex and lenticular & $\begin{array}{c}\text { lenticular to } \\
\text { asymmetrically biconvex }\end{array}$ \\
\hline Peripheral outline & $\begin{array}{c}\text { subcircular and more } \\
\text { lobulate in the ultimate } \\
\text { half }\end{array}$ & $\begin{array}{l}\text { subcircular to faintly } \\
\text { lobulate }\end{array}$ & $\begin{array}{l}\text { subcircular to faintly } \\
\text { lobulate }\end{array}$ & $\begin{array}{l}\text { subcircular, slightly } \\
\text { lobulate }\end{array}$ \\
\hline Periphery & subangular & angular & angular & angular \\
\hline Keel & poorly developed & $\begin{array}{l}\text { faintly developed and } \\
\text { slightly thickened }\end{array}$ & well developed & - \\
\hline $\begin{array}{c}\text { Sutures } \\
\text { (ventral side) }\end{array}$ & radial-slightly arcuate & $\begin{array}{l}\text { radial to slightly arcuate, } \\
\text { flush at the periphery }\end{array}$ & $\begin{array}{l}\text { radial and deeply depressed } \\
\text { towards de umbilical area }\end{array}$ & radial to slightly arcuate \\
\hline $\begin{array}{c}\text { Sutures } \\
\text { (dorsal side) }\end{array}$ & $\begin{array}{l}\text { slightly to distinctly } \\
\text { arcuate }\end{array}$ & $\begin{array}{l}\text { slightly arcuate, flush with } \\
\text { the surface }\end{array}$ & $\begin{array}{l}\text { slightly arcuate, flush with } \\
\text { the surface }\end{array}$ & $\begin{array}{l}\text { slightly to distinctly } \\
\text { arcuate }\end{array}$ \\
\hline $\begin{array}{l}\text { Ornamentation } \\
\text { (ventral side) }\end{array}$ & $\begin{array}{l}\text { covered by } \\
\text { minute pustules }\end{array}$ & larger and denser pustules & $\begin{array}{l}\text { pustules fuse to produce } \\
\text { larger forms }\end{array}$ & $\begin{array}{l}\text { densely pustulated } \\
\text { umbilicus and along } \\
\text { interlocular spaces }\end{array}$ \\
\hline
\end{tabular}


lenticular (see above and Table 1). The pattern of convexity displayed during ontogeny in Buccella thus matches the figures and descriptions of $B$. peruviana of d'Orbigny (1839), of juvenile to adult forms of $B$. peruviana f. typica of Boltovskoy et al. (1980), B. peruviana f. campsi of Boltovskoy et al. (1980), B. karsteni (Reuss) of Heron-Allen \& Earland (1932) and B. alvarezii (d'Orbigny) of Heron-Allen $\&$ Earland (1932).

The documentation presented herein also reveals that the transformation of test convexity, from juvenile to adult, is accompanied by the development of a pronounced keel at the periphery of the test. While juvenile forms exhibit an angular periphery, adolescent and, in particular, the larger adult test, have a keel. Similar morphological transformations in test convexity and the development of a pronounced keel have also been observed in other trochospiral foraminifera (e.g. genus Ammonia, as discussed by Hottinger et al., 1993). The development of a pronounced keel or other ornamental test structures is a common feature in many bilamellar perforate foraminifera, where the outer lamella lays down a complete layer of calcite over the previously formed test (Gronlund \& Hansen, 1976). The repeated lamellation during individual growth stages, ultimately results in substantial morphological changes expressed during ontogeny. The thickening of the peripheral keel in Buccella also results in a less lobulated test, at least in the older parts of the ultimate coil.

The ontogenetic development and form of the keel in Buccella thus agrees well with the figures and descriptions of B. peruviana of d'Orbigny (1839), B. peruviana f. typica of Boltovskoy et al. (1980), adult forms of B. peruviana $\mathrm{f}$. campsi of Boltovskoy et al. (1980), B. karsteni (Reuss) of Heron-Allen \& Earland (1932) and B. alvarezii (d'Orbigny) of Heron-Allen \& Earland (1932). Most adolescent and all adult specimens of Buccella from Bahía Blanca have a keel along the peripheral test margin. Interestingly, the lack of a keel is a feature that characterizes the original description of $B$. frigida (Cushman, 1921) from Arctic waters of the Hudson Bay.

Observations on morphogenetic transformations during test growth also show that other test features are displayed as ontogenetic changes in Buccella. They include the shape of the chambers, the thickening of ornamentation on the umbilical test side and the form and curvature of the sutures. In general, the secondary lamellation in some perforate foraminifera increases the test thickness of preceding chambers and the external ornamental test features. In Buccella, the secondary lamellation gradually covers the antepenultimate and earlier test chambers and covers the pustules within the umbilicus and the interlocular intraseptal spaces. As a result, the width, height and thickness of the pustules are larger within the umbilical region eventually leading to a fusion of pustules and foliar chamber appendages. The dense pattern of pustulation is most pronounced in adult test of Buccella, thus supporting the conclusion that only a single species of Buccella is present within the Bahía Blanca estuary. This pattern thus concurs with the figures and descriptions of $B$. peruviana of d'Orbigny (1839), B. peruviana f. typica of Boltovskoy et al. (1980), B. peruviana f. campsi of Boltovskoy et al. (1980), B. karsteni
(Reuss) of Heron-Allen \& Earland (1932) and B. alvarezii (d'Orbigny) of Heron-Allen \& Earland (1932).

Ontogenetic test modifications in Buccella are also displayed in the shape and form of the chambers. In juvenile individuals of Buccella (five chambers), the chambers on the ventral side are broadly triangular, gradually increasing in size as added and commonly slightly inflated. The inflation of chambers is more pronounced on the ventral than on the dorsal side, resulting in a somewhat asymmetrical ventral, but still biconvex test shape. In adolescent and in particular in adult tests of Buccella, the number of chambers per whorl increases (from five to nine) and the inflation of chambers is reduced on the ventral side. In addition, the sutural incisions and coverage by pustules is more distinct. This ultimately results in typical pie-like triangular chambers as described from adult forms of B. peruviana of d'Orbigny (1839), B. peruviana f. typica of Boltovskoy et al. (1980), B. peruviana f. campsi of Boltovskoy et al. (1980), and B. karsteni (Reuss) of Heron-Allen \& Earland (1932).

The form and shape of sutural lines of Buccella are fairly similar among the species described so far. In the specimens from the Bahía Blanca estuary they were found to be slightly arcuate and generally flush on the dorsal side and mostly radial or faintly curved and deeply depressed on the ventral side. Shape, degree of curvature and incision of the sutures thus agree well with the sutures described from B. peruviana of d'Orbigny (1839), B. peruviana f. typica of Boltovskoy et al. (1980), B. peruviana f. campsi of Boltovskoy et al. (1980), B. karsteni (Reuss) of Heron-Allen \& Earland (1932), and B. alvarezii (d'Orbigny) of Heron-Allen \& Earland (1932).

The morphological analysis of juvenile, adolescent and adult test shows that a continuous series of morphogenetic transformations characterizes ontogenetic development of the benthic foraminifer Buccella. As outlined above, the sequence of morphological transformations concerns the following features: test and chamber shape, convexity, curvature of sutures, development of a keel and ornamental structures. The expression of specific morphological varieties during ontogeny has previously been considered to be terminal stages of individual species. As documented above, at least five different species of Buccella were previously recorded from around South America. The present study indicates, however, that the ontogenetic changes represent a sequence of transitional stages of a single species of Buccella. For species designations is therefore concluded that ontogenetic transformations inherently are more informative than selected features of morphology (see also Langer \& Schmidt-Sinns, 2006; Makled \& Langer, 2010). As such these authors support the conclusion of Boltovskoy (1970), that only a single species of Buccella is present along the coast of South America and that the appropriate designation is B. peruviana (d'Orbigny, 1839).

Buccella peruviana of d'Orbigny represents the terminal adult stage and the earliest described form from the region. This study on juvenile, adolescent and adult phenotypes shows that the morphogenetic stages do not represent end members of individual species, subspecies or varieties, but a sequence of ontogenetic transformations that ultimately result in the 
morphotype that was originally described and depicted by d'Orbigny (1939) under the name Rotalina peruviana. Because $B$. peruviana is the only taxon that unites all features observed during ontogeny and represents the oldest species of Buccella described from this region, the authors consider it the most appropriate taxon designation. The ontogenetic stages include all features previously described from other Recent South American species of Buccella and this paper therefore conclude that only a single species of Buccella, i.e., B. peruviana, lives around South America. This includes the juvenile morphotypes with angular or subrounded periphery that were previously considered to be B. frigida (Cushman) or $B$. karsteni (Reuss), the adolescent phenotypes that were often designated to be either a variety of $B$. karsteni (Reuss), B. peruviana f. frigida (Boltovskoy), B. peruviana f. campsi (Boltovskoy), B. alvarezii (d'Orbigny), or B. frigida (Cushman). As outlined by Theyer (1966), the expression of individual growth stages bears a potential for paleoenvironmental and paleoecological studies in shallow waters around South America (e.g. Armynot du Châtelet et al., 2010).

The morphotypes previously considered to be Buccella frigida of Cushman, a species that was originally described from Arctic waters, were here shown to represent the juvenile stages of Buccella peruviana (d'Orbigny). For the time being, the authors therefore consider the Arctic foraminifer B. frigida of Cushman a separate species that has not yet been reported around South America. Future molecular analysis may reveal whether B. frigida is indeed a separate species, and if it has crossed the equator to South America. From the biogeographic records available to date, the modern distribution of B. peruviana now includes the area between Callao (Peru) and São Paulo (Brazil).

\section{CONCLUSIONS}

The study of individual growth stages of the foraminifer Buccella leads to the following conclusions: (i) detailed morphological analysis shows that a complete series of ontogenetic growth stages of the foraminifer Buccella has been recovered from the Bahía Blanca estuary (Argentina). The stages expressed during growth display a continuous morphogenetic record and indicate the presence of a single species of Buccella (juvenile to adult); (ii) juvenile, adolescent and adult morphotypes of South American specimens of Buccella do not represent end members of individual species, subspecies, forms or varieties, but constitute a continuous sequence of ontogenetic stages that ultimately result in the morphotype that was originally described and depicted by d'Orbigny (1839) under the name Rotalina peruviana. The patterns of biogeographic morphotypes displayed around South America bear a potential for paleoenvironmental and paleoecological studies; (iii) the consideration of ontogenetic stages and putative consequences for species delineations and taxonomy in species of Buccella require a reconsideration of previous views on the biogeographic distribution of $B$. peruviana around South America. From the records available to date, the modern distribution of $B$. peruviana now includes the area between Callao (Peru, South Pacific) and São Paulo (Brazil, South Atlantic); (iv) to document the presence of the Arctic species B. frigida (Cushman, 1921) future molecular analysis are required.

\section{ACKNOWLEDGEMENTS}

The authors are grateful to G. Cusminsky, E.A. Gómez, P. Pratolongo and G. Perillo for providing sample material and support with the field work. W. Makled and personnel from the Centro Atómico Bariloche (Argentina) assisted with the SEM preparation. The authors also thank G. Cusminsky for comments on an earlier draft; A. Weinmann for additional information concerning the distribution of Buccella; S. Camacho for the translation of the abstract; and M. McGann and C. Bonetti for their constructive comments that helped to improve the manuscript. LCM wishes to dedicate this work in memory of her beloved advisor and teacher S. Ballent. This study was supported by a grant from the DAAD awarded to $\operatorname{LCM}(\mathrm{A} / 08 / 74855)$ and the Deutsche Forschungsgemeinschaft awarded to ML (La 884/10-1). It was partially funded by the projects PICT 26057, PICT07/109, PIP 6416/04 and PIP 112-200801-00819 from the Argentinian Research Council.

\section{REFERENCES}

Alperin, A.I.; Cusminsky, G.C. \& Bernasconi, E. 2011. Benthic foraminiferal morphogroups on the Argentine continental shelf. Journal of Foraminiferal Research, 41:155-166. doi:10.2113/ gsjfr.41.2.155

Armynot du Châtelet, E.; Gebhardt, K. \& Langer, M.R. 2010. Foraminifera as tracers of environmental perturbation in the port of Boulogne-sur-Mer (Northern France). Neues Jahrbuch für Geologie und Paläontologie, 262:91-116. doi:10.1127/0077-7749//2011/0187

Bernasconi, E. 2006. Los foraminiferos del Holoceno de testigos de la plataforma continental argentina $\left(40^{\circ} 30^{\prime}-42^{\circ} 48^{\prime}\right.$ y $\left.59^{\circ} 25^{\prime}-64^{\circ} 40^{\prime}\right)$. Universidad Nacional del Comahue, Ph.D. thesis, 210 p.

Boltovskoy, E.1954a. Foraminíferos del golfo San Jorge. Revista del Instituto Nacional de Investigaciones y Museo Argentino de Ciencias Naturales Bernardino Rivadavia, Ciencias Geológicas, 3:85-246.

Boltovskoy, E.1954b. Foraminíferos de la Bahía San Blas. Revista del Instituto Nacional de Investigaciones y Museo Argentino de Ciencias Naturales Bernardino Rivadavia, Ciencias Geológicas, 3:247-300.

Boltovskoy, E. 1957. Los foraminíferos del estuario del Río de La Plata y su zona de influencia. Revista del Instituto Nacional de Investigaciones y Museo de Ciencias Naturales Argentino Bernardino Rivadavia, Ciencias Geológicas, 6:1-77.

Boltovskoy, E. 1959. Foraminifera as biological indicators in the study of ocean currents. Micropaleontology, 5:473-481.

Boltovskoy, E. 1963. The litoral foraminiferal biocoenosis of Puerto Deseado (Patagonia, Argentina). Contributions from the Cushman Foundation for Foraminiferal Research, 14:58-70.

Boltovskoy, E. 1965. Los Foraminiferos Recientes. $1^{\text {a }}$ ed. Buenos Aires, Eudeba, 510 p.

Boltovskoy, E. 1970. Distribution of the marine littoral Foraminifera in Argentina, Uruguay and Southern Brazil. Marine Biology, 6:335-344.

Boltovskoy, E. 1976. Distribution of Recent Foraminifera of the 
South American region. In: R.H. Hedley \& C.G. Adams (eds.) Foraminifera 2, Academic Press, p. 171-236.

Boltovskoy, E. \& Theyer, F. 1965. Neuere Daten über rezente Foraminiferen Zentralchiles. Beitrage zur Neotropical Fauna, 4:143-149.

Boltovskoy, E.; Giussani, G.; Watanabe, S. \& Wright, R. 1980. Atlas of benthic shelf Foraminifera to the southwest Atlantic. New York, The Hague, 174 p.

Brady. H.B. 1884. Report on the Foraminifera dredged by H.M.S. Challenger during the years 1873-1876. Zoology, 9:1-814.

Calvo-Marcilese, L. 2011. Sistemática y paleoecología de los Foraminifera (Protista) del Holoceno del área del estuario de Bahía Blanca, Argentina. Universidad Nacional de La Plata, Ph.D. thesis, 253 p.

Calvo Marcilese, L.; Cusminsky, G.C. \& Gómez, E.A. 2011. Asociaciones de foraminíferos bentónicos en secciones holocenas del estuario de Bahía Blanca (Buenos Aires, Argentina). Ameghiniana, 48:210-225.

Calvo-Marcilese, L. \& Pratolongo, P. 2009. Foraminíferos de marismas y llanuras de marea del estuario de Bahía Blanca, Argentina: distribución e implicaciones ambientales. Revista Española de Micropaleontología, 41:315-332.

Calvo-Marcilese, L. \& Langer, M.R. 2010. Breaching biogeographic barriers: the invasion of Haynesina germanica (Foraminifera, Protista) in the Bahía Blanca estuary, Argentina. Biological Invasions, 12:3299-3306. doi:10.1007/s10530-010-9723-x

Caramés, A. \& Malumián, N. 2000. Foraminíferos bentónicos del Cenozoico del Pozo Estrella x-1, Cuenca del Colorado, plataforma continental argentina. Ameghiniana, 37:387-419.

Closs, D. \& Barberena, M.C. 1960. Faunal studies of Recent Foraminifera from the shore sand of Rio Grande do Sul. Contributions from the Cushman Foundation for Foraminiferal Research, 13:76-78.

Cushman, J.A. 1921. Results of the Hudson Bay Expedition, 1920. I. The Foraminifera. Contribution to Canadian Biology, 1:135-147.

Cushman, J.A. \& Kellett, B. 1929. Recent Foraminifera from the west coast of South America. Proceedings of the United States National Museum, 75:1-16.

Cushman, J.A. \& Parker, F.L. 1931. Recent Foraminifera from the Atlantic coast of South America. Proceedings of the United States National Museum, 80:1-24.

Cusminsky, G.C.; Bernasconi, E. \& Calvo-Marcilese, L. 2009. Holocene benthic Foraminifera from Bahía Blanca estuary: a review and update of systematic and palaeoenvironmental aspects. The Holocene, 19:1-11. doi:10.1177/0959683609345085

Cusminsky, G.C.; Martínez, D. \& Bernasconi, E. 2006. Foraminíferos y ostrácodos de sedimentos recientes del estuario de Bahía Blanca, Argentina. Revista Española de Micropaleontología, 38:395-410.

d'Orbigny, A.D. 1839. Voyage dans 1'Amérique méridionale, Foraminifères. Annales des Sciences Naturelles, 5:1-86.

Eichler, P.P.; Eichler, B.B.; Bruner de Miranda, L. \& Rosch Rodrigues, A. 2007. Modern foraminiferal facies in a subtropical estuarine channel, Bertioga, São Paulo, Brazil. Journal of Foraminiferal Research, 37:234-247. doi:10.2113/gsjfr.37.3.234

Ferrero, L. 2006. Micropaleontología y paleoecología del Cuaternario del sudeste de la provincia de Buenos Aires. Universidad Nacional de Mar del Plata, Ph.D. thesis, 371 p.
Gómez, E.A.; Martínez, D.E.; Borel, C.M.; Guerstein, G.R. \& Cusminsky, G.C. 2005. Submarine evidences of Holocene sea-level fluctuations in the Bahia Blanca estuary, Argentina. Journal of South American Earth Sciences, 20:139-155.

Grønlund, H. \& Hansen, H. J. 1976. Scanning electron microscopy of some recent and fossil nodosariid foraminifera. Bulletin of the Geological Society of Denmark, 25:121-134.

Heron-Allen, E. \& Earland, A. 1932. Foraminifera, part 1: the ice-free area of the Falkland Islands and adjacent seas. Discovery Reports, 4:291-459.

Hottinger, L.; Halicz, E. \& Reiss, Z. 1993: Recent Foraminiferida from the Gulf of Aqaba, Red Sea. Slovenska Akadademija Znanosti in Umetnosti, 33:1-179.

Langer, M.R. \& Schmidt-Sinns, J. 2006. Architecture, ontogenetic development and biogeographic distribution of Cribroelphidium mirum, a new species of benthic foraminifera from South Africa and Namibia (S-Atlantic Ocean). Neues Jahrbuch für Geologie und Paläontologie, Monatshefte, 11:667-682.

Laprida, C. 1998. Micropaleontological assemblages (Foraminiferida and Ostracoda) from Late Quaternary marginal marine environments (Destacamento Río Salado Formation), Salado Basin, Argentina. Revue de Paléobiologie, 17:461-478.

Laprida, C.; García Chapori, N.; Violante, R.A. \& Compagnucci, R.H. 2007. Mid-Holocene evolution and paleoenvironments of the shoreface-offshore transition, north-eastern Argentina: new evidence based on benthic microfauna. Marine Geology, 240:43-56

Makled, W. \& Langer, M.R. 2010. Preferential selection of titanium-bearing minerals in agglutinated Foraminifera: ilmenite (FeTiO3) in Textularia hauerii d'Orbigny from the Bazaruto Archipelago, Mozambique. Revue de Micropaléontologie, 53:163-173. doi:10.1016/j.revmic.2009.11.001

Parker, W.K. \& Jones, T.R. 1865. On some Foraminifera from the North Atlantic and Arctic Oceans, including Davis Straits and Baffin's Bay. Philosophical Transactions of the Royal Society of London, 155:325-441.

Purvis, A. \& Hector, A. 2000. Getting the measure of biodiversity. Nature, 405: 212-219. doi:10.1038/35012221

Reuss, A.E. 1855. Ein Beitrag zur genaueren Kenntnis der Kreidegebilde Mecklenburgs. Zeitschrift der Deutschen Geologischen Gesellschaft, 7:261-191.

Sala, E. \& Knowlton, N. 2006. Global marine biodiversity trends. Annual Review of Environment and Resource, 31:93-122.

Sprechmann, P. 1978. The paleoecology and paleogeography of the Uruguayan coastal area during the Neogene and Quaternary. Zitteliana, 4:3-72.

Theyer, F. 1966. Variationstatische Untersuchungen zur Verbreitung der Gattung Buccella Andersen im Südlichen Teil Südamerikas (Protozoa, Foraminifera). Zoologische Jahrbücher Abteilung für Systematik, 8:203-222.

Tittensor, D.P.; Camilo, M.; Jetz, W.; Lotze, H.K.; Ricard, D.E.; Berghe,V. $\&$ Worm, B. 2010. Global patterns and predictors of marine biodiversity across taxa. Nature, 466:1098-1101. doi:10.1038/nature0932

Received in May, 2011; accepted in January, 2012. 